\title{
COVID-19 MITIGATION MEASURES, ECONOMIC IMPACT AND FACTORS IN RECOVERY
}

\author{
ILMĀRS RIMŠẼIČS ${ }^{1}$ \\ University of Latvia (Latvia)
}

\begin{abstract}
The purpose of the paper is to analyse various factors influencing the speed of recovery and the return to the Old Normal, i.e., GDP levels of 2019 Q4. Most countries have imposed strong Covid-19 containment measures. The research paper reveals various implications of the Covid-19 mitigation policies on GDP growth, the budget deficit and the increase in the outstanding public debt. The analysis will show various correlations between the stringency of containment measures and the mobility of the population and the relationship with the decrease in GDP. It concludes that the size of the fiscal response is important, but does not guarantee immediate recovery. Besides monetary and fiscal policy, there are also other important elements, such as the strictness of the containment measures, the size of the tourism sector, the size of the outstanding pre-crisis debt level, and the quality of governance, which for many countries warrants a smaller decline in GDP. The paper concludes that countries with, on average, less stringent containment measures, with less accumulated pre-crisis public debt, a smaller tourism sector and more efficient governance, tend to have a smaller GDP slowdown and smaller budget deficits, and will recover sooner to pre-crisis levels.

KEY WORDS: Covid-19 crisis, mitigation measures, stringency index, mobility index, budget deficit and public debt.
\end{abstract}

JEL CODES: E63, H12, O11, I15, H6.

DOI: http://dx.doi.org/10.15181/rfds.v34i2.2254

\section{Introduction}

This is a crisis like no other, and there is substantial uncertainty about its impact on people's lives and livelihoods (Gopinath, 2020: 2). At the outset of the crisis, many policy makers introduced containment measures in a 'copy-paste' mode. There was little time to analyse thoroughly what kind of virus had 'visited' us from China, and what the implications are. Only one thing was clear, that we need to act, and to act fast. The stringency and scope of various lockdown measures had an immense negative impact on economic growth. The aim of this paper is to analyse the consequences of the mitigation measures on economic activity, what the most important factors impacting economic recovery are, and whether these factors could be addressed during the crisis. Later, Angelini et al. (2020: 4) expand the discussion on the optimal lockdown policy, recognising clearly that lockdowns increase the cost of recession, but save roughly half a million lives, and if implemented fast at the outset of the pandemic, the measures can slow down the spread of the virus and yield economic benefits.

The availability of financial resources will not be discussed in this paper. However, many countries had to turn to the IMF, and to sign special assistance programmes, in order to receive crisis funding. The countries studied in this paper are recognised as advanced economies with investment-grade ratings belonging to OECD countries. A total of 19 of them are even in the European Monetary Union (EMU), and others conduct their own monetary policies and have floating exchange rate regimes. Thus, they are able to provide additional monetary and fiscal policy stimulus instruments to their economies.

Ilmārs Rimšēvičs - PhD student, University of Latvia, Faculty of Business Administration and Economics

Scientific interests: interaction of monetary and fiscal policy, crisis management and the performance of government, macroeconomic development and structural reforms

E-mail: Ilmarsroma@gmail.com

Tel. +37125725396 
With seemingly no financial availability constraints attached to the rescue exercise of falling GDP in the respective OECD country sample, there are, however, several factors precluding the respective economies from speedy recovery (Sapir, 2020: 4-7).

The first and most obvious factor is the structure of the economy. Clearly, countries with a larger slice of the tourism market and branches of the economy related to the tourism sector will bear the brunt more than countries with a smaller tourism sector. The simple statistical analysis of people employed in economic branches related to tourism allows us to ascertain this factor. The second factor is the stringency of the containment or mitigation measures, which influences considerably people's mobility, and reduces economic activity. At the beginning of the crisis, every government tried to do 'whatever it takes' to prevent people from dying, by introducing various mitigation measures for the Covid-19 pandemic. Governments initially restricted people from attending work in person, closed many businesses in the service and hospitality sectors, and limited the movement of residents. Depending on the severity of these restrictions, people changed their day-to-day activities. Thus, they were forced to reduce socialising and going to shops, cinemas, theatres, bars, restaurants, gyms, etc. The Oxford University Blavatnik School of Government has developed the Oxford Covid-19 Government Response Tracker or Stringency Index (OxCGRT, Oxford University, 2020; Hale et al., 2020: 3), which systematically collects information about 18 different policy measures, such as school closures, workplace closures, travel restrictions, etc. Although at first glance the mitigation policies imposed seemed like a 'copy-paste' approach, they were not. Every country had its own path, and this is reflected in the Oxford Stringency Index. In order to measure the impact of the containment measures, Google created its Google Covid-19 Community Mobility Reports (Google, 2020: 1). These are two very useful databases for the analysis of how the strictness of the containment measures has influenced the mobility of people, and how the reduction of mobility has slowed down the economies. The analysis reflects clearly the fact that more stringent mitigation measures inflicted on the mobility of the population decrease economic activity more. The third factor is outstanding accumulated public debt before the Covid-19 crisis. The study reveals that even though the respective central banks were providing the necessary liquidity, governments need to borrow significantly from markets in order to provide various support measures. Countries with higher outstanding accumulated debt had a larger slowdown in GDP than countries with smaller levels of public debt. Fourth, the effectiveness of governance. The World Bank has produced another index, Worldwide Governance Indicators (WGI), measuring the capability to manage and govern the country (World Bank, 2019: 1). It turns out that governments with more efficient governance tend to perform better during a crisis. This crisis has so far not been an exception.

In this paper, I study the strictness of the containment measures and the consequences of these decisions, because they come at a certain price, and the price is high. It is therefore important to use resources efficiently, knowing that the pandemic could be protracted. A crisis like this requires very close coordination of macro policies, both fiscal and monetary complementing each other (Lagarde, 2020: 1). It has often been concluded that during previous crises, the supportive monetary response has been delayed, thus causing a fall in aggregate demand, and later on a drop in aggregate supply. This time, the central banks have been acting preemptively, taking into account the first available signs of the looming crisis (De Santis, Van der Veken, 2020: 2-6), thus letting the fiscal policy take care of the rest. The amount of the initial stimulus packages at the beginning was unprecedented. 'Governments' economic responses to the crisis is unprecedented, too: $\$ 10$ trillion announced just in first two months which is three times more than response to 2008-2009 Great Financial Crisis. Western European countries allocated close to $\$ 4$ trillion, an amount almost 30 times larger than today's value of the Marshall Plan' (Cassim et al., 2020: 1-2). When it comes to the closer analysis of who has allocated the largest relief packages, then there are no surprises. Advanced economies and high-income countries with better credit ratings and access to financial markets have deployed larger amounts than emerging market countries (Benmelech, Tzur-Ilan, 2020: 1-5). But interestingly enough, so far there is little evidence that the availability of larger and more sizeable amounts of financial resources, liquidity support, guarantees and investments, warrants immediate success, i.e., a faster and smoother recovery and a smaller GDP decline. The second and third waves of Covid-19 have also reemerged, with fresh discussions on whether such expansionary fiscal policies are sustainable in the long run. As the Covid-19 crisis unravels, it becomes clear that there will be a need to increase the size of the fiscal response package. This increase would require additional financial 
resources. Therefore, it is important to analyse the factors which play an important role in defining the future course of recovery of each country, thus decreasing the need to allocate larger financial resources in the future, especially knowing that several countries could run out of remaining fiscal space.

Since the Covid-19 crisis could be long and protracted, it is important to analyse all other factors affecting the borrowing and use of fiscal resources. Thus, it is equally important to establish an effective policy mix, e.g., the appropriate lockdown policy measures, and to safeguard the possibility to borrow during crises and to improve the quality of governance, in order to manage the distribution of critical funding throughout all economic sectors and channels and various population groups. However, the speed and clarity of the implementation of fiscal measures (guarantees, loans, tax deferrals, equity investments, furlough and part-time work payouts, etc) discipline, commitment and solidarity throughout crises are also equally important factors in defining successful recovery and regaining the previous levels of GDP, namely 2019 Q4.

\section{Theoretical background}

In order to understand the drama which every government is facing during the Covid-19 crisis, and the choices in imposing various infection containment measures, Andersen et al. (2020:1-17) have produced an excellent paper reflecting these issues. The Scandinavian experience is often used as the best proxy, because Sweden imposed rather mild restrictions (recommendations), while neighbouring countries imposed more stringent lockdown measures. Juranek et al. (2020: 1-2,15) make a good analysis of the alternative containment policy in Sweden to the other approaches discussed in mainstream research. The example of Sweden provides a good alternative for future decision making, especially during the time of the second wave. It also encourages us to study the Swedish experience closer, and to analyse why Swedish epidemiologists took such controversial and different decisions at the outset of the crisis. Rachel (2020: 4-5) argues that the best approach to minimising the spread of infection is targeted isolation, because it is the least costly and improves the medical situation.

Two important data sets were developed at the outset of the Covid-19 crisis, which could serve as a guiding light for future decision making: the Oxford Stringency Index, measuring the stringency of the containment measures imposed, and the Google Covid-19 Mobility Report or Mobility Index, measuring the reduction of the mobility of people due to imposed and not imposed (voluntary) measures. They provide much information on the influence of mitigation measures on the mobility of people. Elgin et al. (2020:1) have surveyed the economic measures governments around the globe have taken in response to the global pandemic, providing grounds for different policy variable analysis. Letzing (2020: 1) also iterates the importance of government support, but asks the question, can governments in times of increasing budget deficits and public debt afford to continue to support, and for how long? There will always be a question as to why the GDP decrease in some countries is larger than in others. According to Sapir (2020: 5-7), there might be several reasons: the stringency of the lockdown measures, the size of the outstanding debt, the size of the tourism and service industry in the respective economy, and the quality of governance. The OECD (2020) provides a basis for a potential policy mix, stressing the steps and measures of how to act, and which areas of the economy and policy making are important in order to minimise the consequences of further fallout.

A further unlimited increase of outstanding debt for some countries does not look viable. In the most pessimistic scenario, 'the loss of output and consumption could persist beyond 10-15 years' (Mihailov, 2020: 4).

\section{Stringency of measures, mobility of population, and the impact on GDP}

The Covid-19 crisis arrived uninvited, and caught countries totally unprepared and by surprise. The media reported a lot of people dying. Something needed to be done, and fast. At the outset of the crisis, in order to contain the spread of the pandemic, governments introduced various pandemic mitigation and containment measures. The Stringency Index is an instrument to gauge and analyse the stringency of introduced non pharmaceutical intervention (NPI) measures, and Google created the Google Mobility Index, another instrument measuring the mobility changes in the population. Both provide an opportunity to compare the consequences that the containment measures and the imposition and reduction of mobility left on each county's GDP. The country sample 
consists of EU countries and additionally selected OECD countries. The outbreak of the pandemic in all these countries was certified at approximately the same time, the countries had a comparable monetary policy, and 19 countries are even united by the European Monetary Union. The borrowing capabilities of all these countries was not limited, although financial markets priced in slightly different risk factors for all these countries. Thus, fiscal policy instruments were available in one form or another. The Stringency Index allows us to see in real time how the stringencies of containment measures have evolved over time, and how average stringencies throughout the year 2020 compare to other countries (Figure 1). The highest average stringency of Italy for the year 2020, and the lowest in Estonia, raise the discussion whether this is the most important factor, and what are the implications for the GDP of different countries with different stringency levels throughout the year.

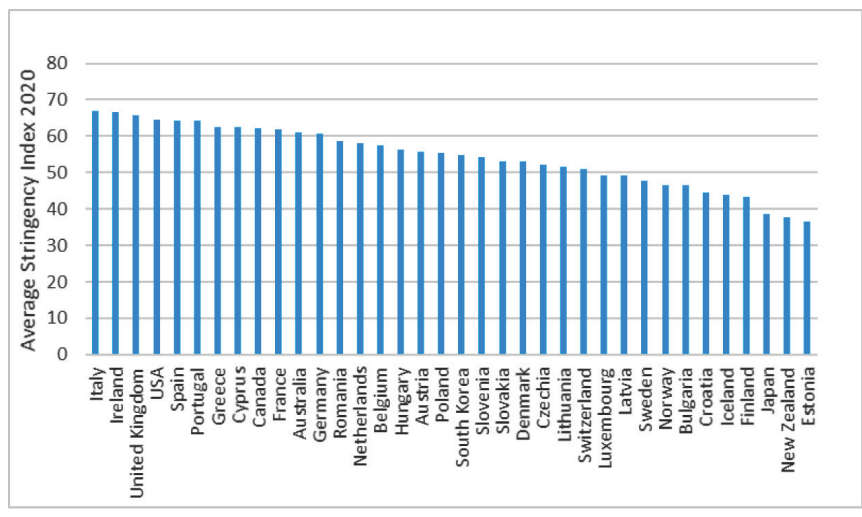

Figure 1. Average Stringency Index (2020)

Source: (OxCGRT, Oxford University, 2020), author's calculations.

With the data of the Average Stringency Index and Google's Mobility Index, it is possible to establish the relationship between the two indices (Figure 2). The results allow us to state that there is a visible correlation between the two indices. Stricter containment measures induce a larger decrease in mobility.

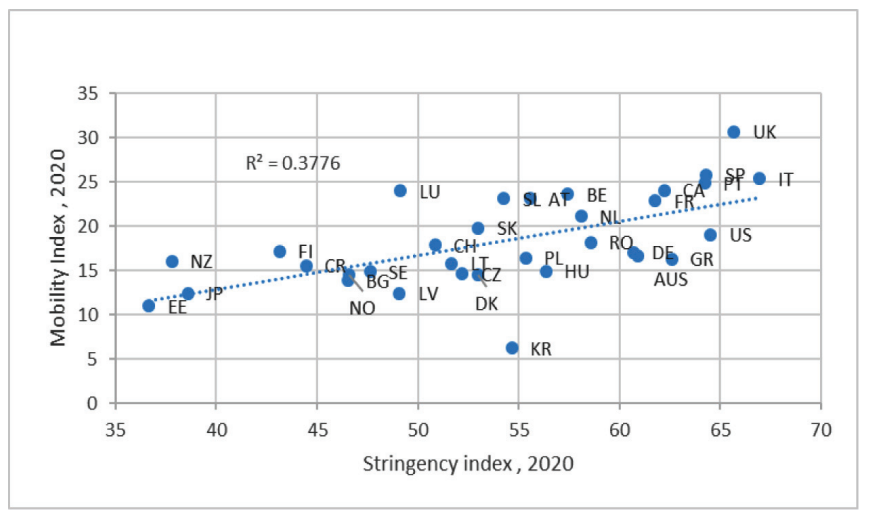

Figure 2. The correlation between the Average Stringency and Average Mobility indices

Source: OxCGRT, Oxford University, 2020; Google (GMR) data, and author's calculations.

Once we have established the fact that there is a close correlation between the stringency of containment measures and the reduction in the mobility of the population, it is important to ascertain the impact of the severity of stringency measures on the reduction of mobility and on the reduction in economic activity and GDP. The results in the autumn about GDP changes in 2020, when only early forecasts from the IMF and 
Eurostat were available, showed us that there will be a sizeable impact on the decrease in GDP due to the imposition of containment measures and the respective reduction in mobility.

During the summer of 2020, the virus outbreak subsided, and countries eased their restrictions. Thus, the stringency of containment measures and the increase in the population's mobility lessened their effects, and 2020 Q3 GDP showed signs of recovery. However, now, when the final data for annual GDP growth levels for the year 2020 have been published, we can again ascertain that the imposition of containment measures and the ensuing reduction in mobility, which is reflected in the Mobility Index, had negative consequences on GDP growth in 2020 (Figure 3).

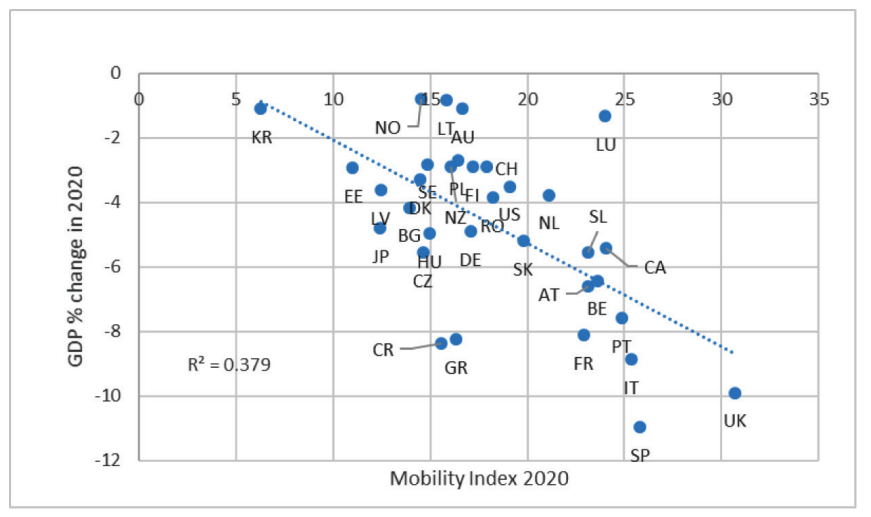

Figure 3. Mobility and GDP decreases in 2020

Source: Eurostat; Google Mobility Report, author's calculations.

In turn, negative GDP growth has negative consequences for the state budget and budget revenues, thus increasing the budget deficits of the respective countries. A larger GDP decrease causes a larger budget deficit (Figure 4). Hence, it is possible to state that the imposition of containment measures has a clear relationship with the increase in the budget deficit and the respective need to borrow, thus increasing outstanding debt levels.

Why GDP is decreasing in some countries more than in others is a matter for further analysis. However, there are several good hypotheses why Covid-19 has different implications for different countries. The stringency of containment measures, which reduces mobility and has serious implications for GDP growth, is only one factor. Before this paper analyses other factors (Sapir 2020: 4-7), it is important to bring the size of fiscal stimulus packages into the equation of the recovery recipe.

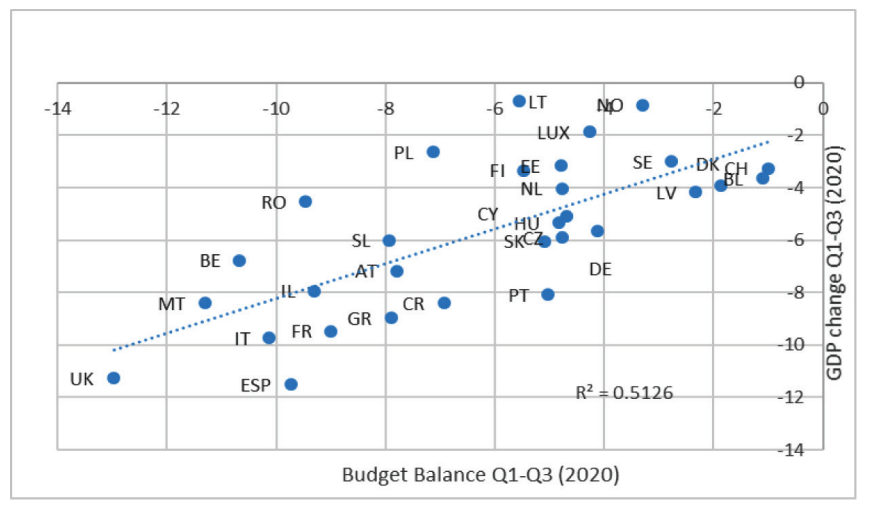

Figure 4. The impact of GDP decrease on budget deficits in $2020^{2}$

Source: Eurostat, author's calculations.

2 Since Eurostat data about respective budget deficits and outstanding debts of the countries will come out only on April 22 2021 , for the time being we are going to use available Eurostat data of the third quarter (2020Q3). As the data will come in, respective Figure will be updated. There are no doubts that conclusions will remain the same. 


\section{Monetary and fiscal stimulus packages}

In order to stop bleeding and to prevent even more severe consequences, governments and the respective parliaments approved several economic relief and stimulus packages. Governments and central banks have mobilised amounts of money unseen before. This time, central banks have relied on early signals and acted preemptively (De Santis, Van der Veken, 2020: 2-6). The ECB has announced several new initiatives, and has increased the amount of the Pandemic Emergency Purchasing Programme (PEPP) to 1.85 trillion euros; and so did other central banks of countries in our sample, as well as passing several new decisions in order to provide liquidity and stabilise financial markets. Governments have also announced many different support and stimulus packages in order to mitigate the consequences of the Covid-19 crisis (Elgin et al., 2020: 1). During the summer, EU leaders agreed to establish the 750-billion-euro Recovery and Resilience Fund (RRF). The most important question is whether the huge resources which have been allocated and will be allocated to stabilise the economic situation and minimise the damage done by Covid-19 will do the job (Cassim et al., 2020: 1-2). The fiscal response to the crisis is very important (Anderson et al., 2020: 1-19), but can we claim that making more money available safeguards a smaller decrease in GDP, a smaller budget deficit, and a smaller increase in public debt?

So far, the results differ. The hypothesis that more money will do the trick and bring recovery sooner has so far not been confirmed. Several (especially rich) countries have provided immense amounts of money and support measures in order to rescue firms and people from the hardships they are going through (Benmelech, Tzur-Ilan, 2020: 1-5), but with little response so far (Figure 5). Budget deficit limits have been lifted, and borrowing has gone wild (Economist, 2020: 1). There are countries which have used large amounts of fiscal stimulus, thus increasing further the outstanding debt levels and budget deficits, and have still not managed to keep the decrease in GDP under control.

On the other hand, Sweden, Finland, Denmark, Norway, Lithuania, Estonia and Latvia, with smaller additional stimulus packages, have kept the increase in their debt levels and their budget deficits lower, and experienced a smaller slowdown in economic activity. Do smaller GDP decreases in the respective countries have something to do with milder Covid-19 containment measures? Yes, but not only. It is important to look at the relatively small GDP decreases in these countries. GDP decreased in 2020 in Norway (-0.8\%), Denmark (-3.3\%), Finland (-2.9\%), Sweden (-2.8\%), Estonia (-2,9\%), Latvia (-3.6\%), and Lithuania (-0.8\%) (IMF 2020), whereas the average decrease in GDP in the EU was $-6.4 \%$ (IMF 2020), and in southern EU countries it was even more.

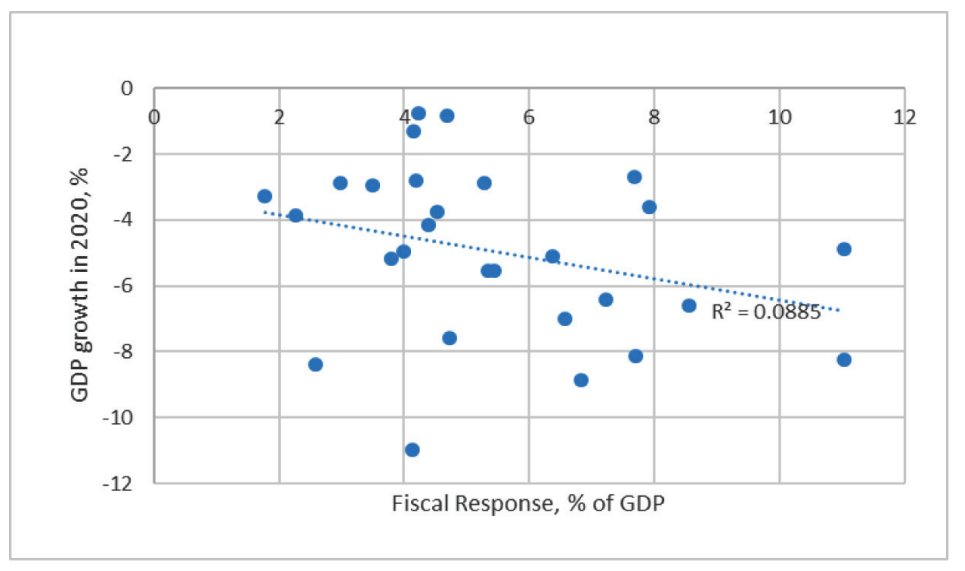

Figure 5. GDP \% change and the respective fiscal respons

Source: IMF Database 2021, author's calculations 


\section{Preconditions and factors for recovery}

Since the Nordic countries and the three Baltic States have also chosen different pandemic containment and mitigation policies, they are often compared, and they serve as a good proxy for different comparisons. In order to have a better representation of the different policies, it would also be important to include other countries in the sample, as representatives of even more different approaches dealing with the containment of the pandemic. The graph shows that stringency varies substantially over the same period. There might be speculation about why and when particular measures were introduced, and whether they could be lifted earlier (Figure 6).

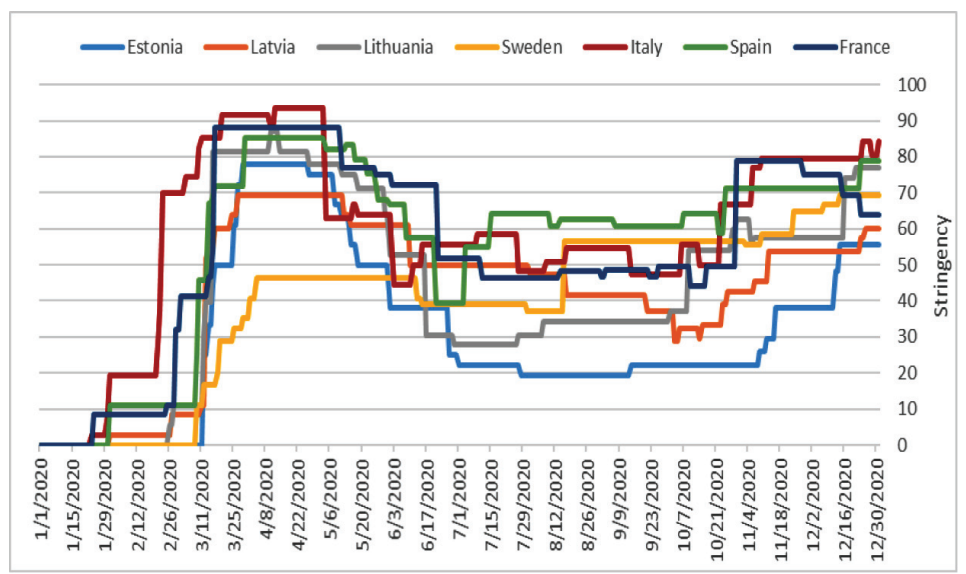

Figure 6. Stringency evolution in seven countries during 2020

Source: OxCGRT, Oxford University, 2020, author's calculations.

It has also been claimed that stricter lockdown measures cause a greater economic slowdown, but there are other factors influencing a decrease in GDP (Sapir, 2020: 5-7).

The current analysis shows that the stringency of the pandemic containment measures has an important effect on the economic activity of the respective country, and therefore the imposition of these measures should be carefully assessed before their introduction, taking into account all the negative factors of health and economic development. Covid-19 containment measures also have a different impact on different industries. There are industries which have not felt a difference since March 2020, and have not laid off any workers, but have hired more. But the service and tourism industries have been hardest hit, and countries where their respective weight in the structure of GDP is higher were affected more than others (Figure 7), thus partially explaining the larger decrease in GDP in these countries.

Besides the stringency of the containment measures and the share of tourism and related service industries in the economy, there are other factors which are also important in the context of the slowdown in GDP. The size of the outstanding debt according to Sapir (2020: 5-7) is another important factor playing an important role in the process of the stabilisation of the economic situation (Figure 8). There is a close correlation between the size of the debt and the decrease in GDP in 2020. The higher the level of accumulated pre-crisis debt is, the larger the decrease in GDP is. 


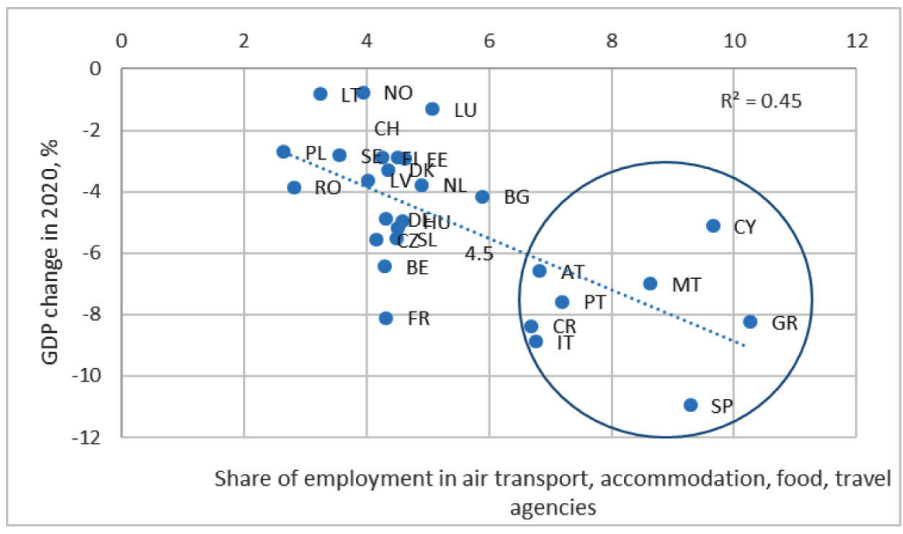

Figure 7. GDP decrease in 2020 due to the sizeable tourism and related services industry

Source: Eurostat, author's calculations.

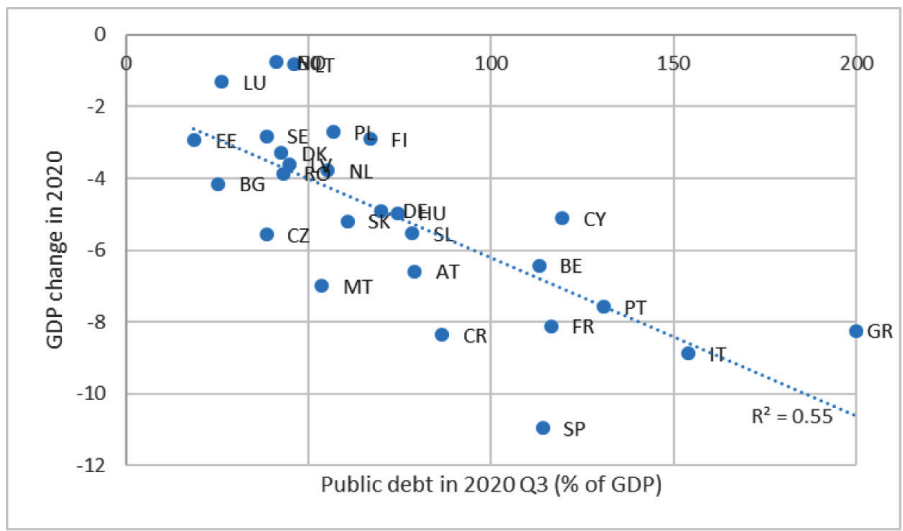

Figure 8. Public debt and GDP change in 2020

Source: Eurostat, author's calculations.

In addition to the factors mentioned above, there are other important factors which could help to resolve the crisis. These factors include having a good team and a well-trained and experienced administrative staff. There could also be administrative or judicial obstacles precluding far-reaching decisions due to the bureaucratic hurdles and other inefficiencies. The World Bank has produced an index, the Worldwide Governance Indicators (WGI), measuring the capability to manage and govern the country (World Bank, 2019: 1). It is called the quality of governance. The government's effectiveness is the closest parameter out of seven (Figure 9), the others being: voice and accountability; political stability and the absence of violence; government effectiveness; regulatory quality; the rule of law; and control of corruption. The correlation between a government's effectiveness and the decrease in GDP is obvious. Countries with a smaller GDP decrease have better government effectiveness in general. It is important to assign the weight of each factor. According to Sapir (2020: 4-7): 'Together, the factors of lockdown strictness, tourism and governance explain nearly 60 percent of the differences between countries in terms of the economic hit from Covid-19.' Since fiscal discipline rules have been lifted in European Union and larger OECD countries conducting their own monetary and fiscal policy, at this point it would be difficult to assign the weight of the accumulated debt to the decrease in GDP. 


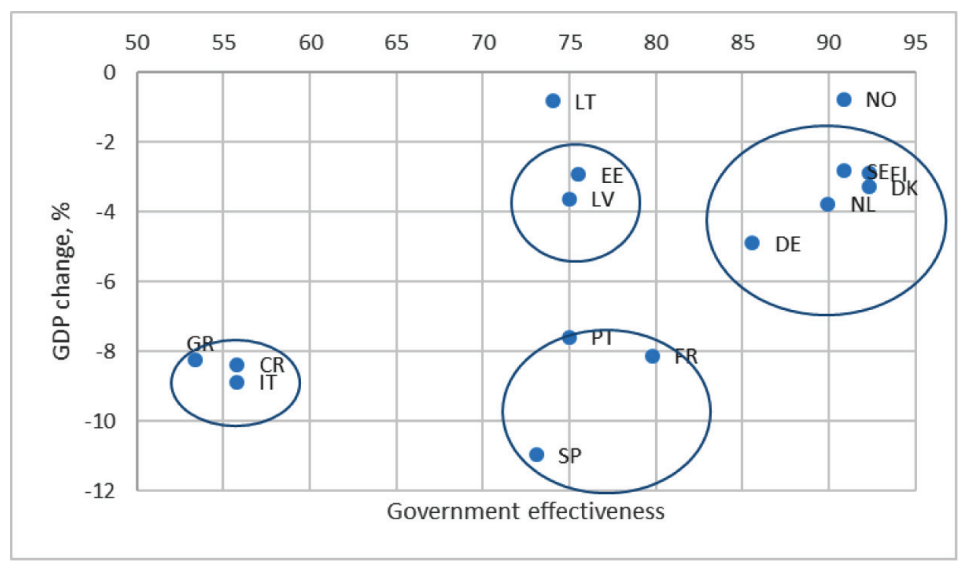

Figure 9. GDP change and government effectiveness

Source: World Bank, author's calculations.

However, there are several other factors which could explain the larger fall in GDP, other things being equal. The speed and length of the implementation of financial relief measures are very important. Countries differ in taking fast, clear and decisive decisions to implement measures through various financial support channels, as does the length of the outstanding support policies (IZA, 2020: 1). Further studies will provide more grounds for these arguments, especially taking into account the fact that there were also several countries which provided direct cash payments to physical and legal persons in order to quickly provide immediate purchasing power and to uphold demand.

There are various reasons and different assumptions of when countries will return to the GDP level of 2019. According to the IMF (2020: 1), only a few countries will be able to reach pre-crisis GDP levels by 2022 and 2023, but unemployment and the public debt for almost all countries will stay at an elevated level for many years, and the 2019 level (Old Normal) will not be reached in the foreseeable future. The second wave of Covid-19 makes the situation even worse. 'High public debt poses significant economic challenges, as it makes the economy less resilient to shocks, and reduces the scope for counter-cyclical fiscal policy' (Burriel et al., 2020: 22).

\section{Towards the optimal policy mix}

Twelve months into the crisis, there is still a debate about the virus, about vaccines, and the stringency of lockdown or mitigation measures. The crisis could be long and exhausting. The second wave of the pandemic is coming to an end, and the third wave of fresh lockdowns is coming before Easter. There could be many waves ahead. Knowing that this economic crisis could be long and protracted, and will probably require more and more new financial resources in order to minimise the consequences of paid furlough, wage subsidies, unemployment benefit expenditure, etc, decisive action has to be taken to address the economic crisis (OECD, 2020: 1-19). The further unlimited increase of outstanding debt for some countries does not look viable. In the most pessimistic scenario, 'the loss of output and consumption could persist beyond 10-15 years' (Mihailov, 2020: 4).

Therefore, it is important to have a long-term vision, and to develop a 'formula' or so-called policy mix, not only for the current Covid-19 type economic crisis, but also for other similar economic crises. It is important to establish the main principles and factors of how to act in the future if a similar pandemic explodes and severe consequences again risk derailing the economies of so many countries (Buti, 2020: 4-5). Despite the much better understanding of crises and better cooperation in comparison with the Great Financial Crisis, the current Resilience and Recovery Plan is still slow in its implementation. As the European Central Bank 
President Christine Lagarde said: 'Governments must make sure to roll out their joint spending plan on time to ensure the region's recovery from the coronavirus pandemic' (Weber, 2021: 1).

Therefore, based on the above analysis, the paper compiles additional guidelines with all-important factors and elements that need to be taken into account when constructing the next relief package and building high-quality communication with the public (Haskel, 2020: 24), so that everybody has a sense of belonging to this exhaustive process of recovery from the pandemic's scars.

However, there are elements in the recovery equation which should be in place at all times: investmentgrade international credit ratings, adequate fiscal space and sustainable debt levels, to withstand the storm even when interest rates rise, good governance, and, of course, the adequate capacity of the medical system to accommodate pandemic patients.

There are many cumbersome procedures to fill in various document forms and prove eligibility for funding. There are schemes which provide just basic financing, calculated with a great time lag, and not providing certainty about the future, and thus not promoting economic activity and not increasing demand for credit and consumption, investment and future spending. Discipline in all respects (epidemiological and financial) is another factor which goes together with quality of governance, trust and commitment, ownership of the process, and solidarity. If this is a Mother of all crises, it requires massive, complex and coordinated action and communication with the public at large.

\section{Conclusions}

In conclusion, it can be stated that since the third wave of Covid-19 has already arrived, countries have experienced new waves of mitigation measures, and the subject of the Covid-19 crisis will not go away any time soon, countries need to have a clear crisis management plan. During the first wave of the pandemic, many countries adopted quite stringent mitigation measures. This study reveals that there is a sizeable correlation between the stringency of the measures and the mobility of the population. The more stringent the containment measures, the more it decreases mobility. In turn, the decreased mobility affects a decrease in GDP. Thus, we could state that stringency has a considerable effect and a close correlation with the decrease in GDP. In turn, the decrease in GDP increases the respective budget deficit levels. Countries have provided unprecedented amounts of money to compensate for the loss of revenue and output. But there have been mixed results so far, without evidence that larger fiscal resources and relief packages have warranted a speedier recovery in GDP. Nordic and Baltic countries with less stringent containment measures have allocated smaller fiscal response packages and have not increased their debt levels and budget deficits substantially, and have experienced a smaller decrease in GDP. It has been stated (Sapir 2020: 6-7) that the strictness of the lockdown, the sectoral size of tourism in the economy, and governance, could explain approximately 60 per cent of the differences in economic performance last year. This paper shows that the average stringencies throughout the year in the Nordic countries and Baltic States were lower than in other countries in the sample. The sizes of the tourism sectors were smaller, and the effectiveness of the governance, according to World Bank indicators, was higher in these countries, which partially explains the smaller fall in GDP. The size of the outstanding accumulated public debts also plays a certain role in the recovery of highly indebted countries. There is a clear correlation between the size of the accumulated debt and the decrease in GDP. Countries with larger public debts had a larger GDP decline. Therefore, other factors in the everyday management of the crisis, e.g., the speed of the implementation of relief measures, the clarity and duration of the support measures, the commitment of policymakers 'to do whatever it takes', and solidarity, are also very important elements to tackle the crisis and to return sooner to GDP levels of 2019. The limitation of this study is associated with the evaluation of the discipline during the respective lockdown, thus overstating the level of actual stringency. However, measuring the decrease in mobility provides a more accurate representation of the impact of the measure of the mitigation of stringency on economic growth. Covid-19 and similar crises could surprise us from time to time; therefore, it would be important to keep all these factors in mind, 
and constantly fulfil the task of improving factors which could not be improved during the crisis, e.g., the public debt level and financial rating of the country, and continue to improve the effectiveness of governance.

\section{References}

Andersen, A. L., Hansen, E. T., Johannesen, N., Sheridan, A. (2020). Pandemic, Shutdown and Consumer Spending. Lessons from Scandinavian Policy Responses to COVID-19, 12.05.2020, p. 1-17.

Anderson, J., Bergamini, E., Brekelmans, S., Cameron, A., Darvas, Z., Domínguez Jíménez, M., Midões, C. (2020). The Fiscal Response to the Economic Fallout from the Coronavirus. Bruegel Datasets, 24.11.2020, p. 1-19.

Angelini, E., Damjanović, M., Pariès, M. D., Zimic, S. (2020). ECB-BASIR: A Primer on the Macroeconomic Implications of the COVID-19 Pandemic. ECB Working Paper Series, No. 2431, p. 4.

Benmelech, E., Tzur-Ilan, N. (2020). The Determinants of Fiscal and Monetary Policies During the Covid-19 Crisis. NBER Working Paper, No. 27461, p. 1-5.

Burriel, P., Checherita-Westphal, C., Jacquinot, P., Schön, M., Stähler, N. (2020). Economic Consequences of High Public Debt: Evidence from Three Large Scale DSGE Models. ECB Working Paper Series, No. 2450, p. 22.

Buti, M. (2020). A tale of two crises: Lessons from the financial crisis to prevent the Great Fragmentation. VOXEU, p. 4-5.

Cassim, Z., Handjiski, B., Schubert, J., Zouaoui, Y. (2020). The 10-trillion Dollar Rescue how Governments Can Deliver Impact. McKinsey\& Company, 05.06.2020, p. 1-2.

De Santis, R. A., Van der Veken, W. (2020). Forecasting Macroeconomic Risk in Real Time: Great and Covid-19 Recessions. ECB Working Paper Series, No. 2436, p. 2-6.

Economist. (2020). Governments must Beware the Lure of Free Money. The Economist, 23.07.2020, p. 1.

Elgin, C., Basbug, G., Yalaman, A. (2020). Economic Policy Responses to a Pandemic: Developing the COVID-19 Economic Stimulus Index. VOXEU, 07.05.2020, p. 1.

Gopinath, G. (2020). The Great Lockdown: Worst Economic Downturn Since the Great Depression. IMFblog, 14.04.2020, p. 2 .

Hale, T., Angrist, N., Cameron-Blake, E., Hallas, L., Kira, B., Majumdar, S., Petherick, A., Phillips, T., Tatlow, H., Webster, S. (2020). Oxford COVID-19 Government Response Tracker. Oxford University, Blavatnik School of Government, p. 3.

Haskel, J. (2020). From Lockdown to Recovery - the Economic Effects of COVID-19, Speech at Imperial Future Matters Online Webinar. Bank of England, 23.07.2020, p. 24.

IMF. (2020). World Economic Outlook, p. 1.

IZA Institute of Labor Economics and the Labor Market. (2020). Crisis Response Monitoring, 25.03.2021, p. 1. Available on line: https://covid-19.iza.org/crisis-monitor/

Juranek, S., Paetzold, J., Winner, H., Zoutman, F. (2020). Labor Market Effects of COVID-19 in Sweden and its Neighbors: Evidence from Novel Administrative Data. Institutt for foretaksøkonomi Department of Business and Management Science, Issue 42, p. 1-2; 15.

Lagarde, C. (2020). Europe's Response to the Crisis. ECB Blog, 23.07.2020, p. 1.

Letzing, J. (2020). How Long Can Governments Keep Spending to stem COVID-19 Job Losses? World Economic Forum, 24.07.2020, p. 1.

Mihailov, A. (2020). Quantifying the Macroeconomic Effects of the COVID-19 Lockdown: Comparative Simulations of the Estimated Galí-SmetsWouters Model. University of Reading, Discussion Paper, No. 07.2020, p. 4.

OECD. (2020). Tax and Fiscal Policy in Response to the Coronavirus Crisis: Strengthening Confidence and Resilience. $O E C D$, p. 1-19.

Rachel, L. (2020). An Analytical Model of Covid-19 Lockdowns: Equilibrium Mitigation Flattens the Epidemic Curve. Optimal Lockdown Does Not, 05.08.2020, p. 4-5.

Sapir, A. (2020). Why has COVID-19 hit different European Union economies so differently? Policy Contribution, No. 18, p. $4-7$.

Weber, A. (2021). ECB's Lagarde Says Governments Must Get Fiscal Stimulus Done. Bloomberg, 18.03.2021, p. 1.

World Bank. (2019). Worldwide Governance Indicators, p. 1. 


\title{
COVID-19 PADARINIŲ ŠALINIMO PRIEMONÉS, EKONOMINIS POVEIKIS IR ATSIGAVIMOVEIKSNIAI
}

\author{
ILMĀRS RIMŠĒVIČS \\ Latvijos universitetas (Latvija)
}

\section{Santrauka}

COVID-19 lėmė krizę, kokios dar nèra buvę. Krizès laikotarpiu taikytos įvairios švelninimo priemonės gana brangiai kainavo: gyventojų mobilumo, taigi ir ekonominės veiklos, mažinimas mažina ir BVP. Šiame straipsnyje kalbama ne apie tai, ar yra geresnių suvaržymo priemonių derinių, kurie lemtų mažesnị pandemijos aukų ir užkrèstų žmonių skaičių, o apie tai, ar jos galètų būti tikslingesnès, labiau drausminančios ir suprantamesnès visuomenei. Akivaizdu, kad visos švelninimo priemonès mažina BVP, lemia didesnę skolą vyriausybių biudžetuose ir didina deficitą.

Siekdamos kompensuoti pajamų praradimą, vyriausybės turi skolintis finansų rinkose ir didinti negrąžintą valstybės skolą. Pažangios ekonomikos šalys išnaudojo nemažai finansinių išteklių, kad sustabdytų tolesnị ekonominès padėties prastėjimą. Remiantis tyrimų duomenimis ir skaičiavimais, galima tikètis, kad ekonomiškai turtingesnių šalių galimybės patekti ị finansų rinkas ir skolintis didesnes pinigų sumas, siekiant jas skirti krizès nulemtiems poreikiams tenkinti, yra didesnès. Reikia pripažinti, kad šiose šalyse ir geriau išvystyta turizmo pramonè bei paslaugų sektorius, kuris esant pandemijai buvo beveik visiškai sustabdytas, tad ir tų šalių skolinimasis didesnis, kartu auga ir visos šalies skola. Turizmo ir paslaugų pramonės, kuri susijusi su turizmo ir svetingumo pramone, nuostolius kompensuoti sudėtinga, nes šis sektorius beveik uždarytas. Krizès laikotarpiu sukauptos ikikrizinės skolos dydžio sumažinti neįmanoma, tad belieka kliautis šalių vyriausybėmis ir jų gebejjimu valdyti krizes. Vyriausybėms ypač svarbus tampa gebejjimas priimti sprendimus ir kuo sparčiau juos igyvendinti bei informuoti visuomenę. Sparta, ypač krizės pradžioje, paskirstant išteklius įmonėms ir žmonėms per trumpiausią įmanomą laiką, ypač svarbi. İsipareigojimas daryti viską, kas būtina, solidarumas ir visų krizès dalyvių bendradarbiavimas yra svarbūs veiksniai, užtikrinantys geresnius rezultatus ilguoju laikotarpiu.

Straipsnyje daroma išvada, kad vertinant ir apibendrinant šalių duomenis, šalyse, kuriose taikomos ne tokios griežtos ribojimo priemonės ir kur buvo mažesnè ikikrizinè valstybės skola, mažesnis turizmo sektorius ir veiksmingesnis valdymas, biudžeto deficitas yra mažesnis, taigi jos greičiau atsistato ir pasiekia iki krizès buvusị lygì.

PAGRINDINIAI ŽODŽIAI: COVID-19 krizè, krizès švelninimo priemonès, griežtumo indeksas, mobilumo indeksas, biudžeto deficitas ir valstybès skola.

JEL KLASIFIKACIJA: E63, H12, O11, I15, H6.

Received: 2021-03-06

Revised: 2021-05-03

Accepted: 2021-05-12 